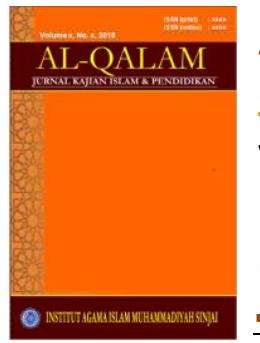

\title{
KONSEP BUDAYA SIRIK NA PACCEDAN PENDIDIKAN KARAKTER (STUDI MODEL PEMBELAJARAN INTEGRATIF)
}

\author{
Oleh: Hardianto Rahman ${ }^{1}$
}

***

\begin{abstract}
Abstrak
Dalam konteks pendidikan pendidikan, dibutuhkan pencarian dan pengembangan kearifan-kearifan lokal (Local Wisdoms), Penerapan kearifan-kearifan lokal (budaya sirik na pace) dalam pendidikan karakter diharapkan mampu membetuk karakter peserta didik sesuai dengan nilainilai yang dianut dalam daerahnya. Selain itu, mereka sadar bahwa leluhur mereka memiliki ajaran-ajaran luhur yang amat menghargai kejujuran, keadilan, dan integritas. Sirik na Pacce (Bahasa Makassar) atau sirik' na Pesse (Bahasa Bugis) adalah dua kata yang tidak dapat dipisahkan dari karakter orang Bugis-Makassar dalam mengarungi kehidupan di dunia ini. Kedua konsept tersebut mutlak untuk di desain dalam bentuk pembelajran integratif dalam rangka memperbaiki sistem pendidikan.
\end{abstract}

Kata Kunci : Pendidikan, karakter, sirik na pacce, integratif

\section{PENDAHULUAN}

T mbas dari system pendidikan di negara ini adalah out put maupun out come pendidikan yang masih melahirkan beberapa orang yang pintar memanipulasi rakyat dengan korupsi, eksploitasi SDA dan asset-asset Nasional yang merupakan harapan rakyat Indonesia dengan menjualnya ke pemodal asing. Kenapa ini terjadi, karena kita hanya membekali anak didik kita dengan kecerdasan intelektual semata. Ranah afektif maupun psikomotorik teori Bloom sangat kurang dalam pembelajaran siswa. Namun sebenarnya walaupun mungkin ketiga teori Bloom ini dipadukan belum tentu kita dapat menghasilkan anak didik yang mempunyai moralitas tinggi.

Belajar dari realitas, pendidikan agama disekolah-sekolah umum terlebih lagi di sekolah agama belum mampu memberikan keyakinan bahwa pendidikan moral/agama adalah solusi dari kebobrakan pendidikan. Dari beberapa media

${ }^{1}$ Dosen Tetap STAI Muhammadiyah Sinjai 


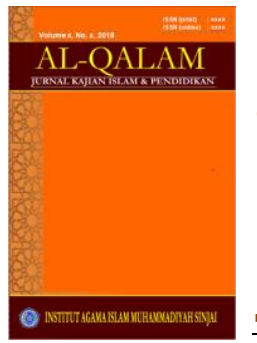

Volume 06 No 022014

ISSN (print) : :1858-4152

ISSN (online) : -

Homepage : http://iournal.iaimsiniai.ac.id/index.php/al-qalam

diberitakan bahwa dari sekian lembaga/kementerian negara yang ada tenyata kementerian agama adalah salah satu deprtemen yang paling kurup. Sekian banyak para pejabat, pengusaha, legislator dan elit poitik yang mengikuti pelatihan ESQ tapi toh belum bisa menyingkirkan mental korup itu.

Lantas apa yang mesti kita lakukan? perlu dilaksanakan reformasi pendidikan ke arah yang lebih kondusif untuk terciptanya kualitas SDM yang berkualitas, terutama melalui pengenalan konsep pendidikan holistik (menyeluruh). Tujuan pendidikan holistik, seperti yang dikatakan oleh J. Krishnamurti, adalah "The highest function of education is to bring about an integrated individual who is capable of dealing with life as a whole".

Sizer dan Sizer mengatakan bahwa tujuan pendidikan selain untuk mempersiapkan manusia untuk masuk ke dalam dunia kerja, adalah untuk membuat manusia dapat berpikir secara menyeluruh serta menjadi manusia yang bijak (thoughtful and decent human being). ${ }^{3}$ Sejak 2500 tahun yang lalu Socrates telah berkata bahwa tujuan yang paling mendasar dari pendidikan adalah untuk membuat seseorang menjadi "good and smart". Manusia yang terdidik seharusnya menjadi orang bijak, yaitu yang dapat menggunakan ilmunya untuk hal-hal yang baik (beramal shaleh), dan dapat hidup secara bijak dalam seluruh aspek kehidupan berkeluarga, bertetangga, bermasyarakat, dan bernegara. Karenanya, sebuah sistem pendidikan yang berhasil adalah yang dapat membentuk manusiamanusia berkarakter berbasis budaya lokal yang sangat diperlukan dalam mewujudkan sebuah Negara kebangsaan yang terhormat.

Budaya adalah salah satu kekuatan sejarah. Pada dasarnya manusia menciptakan budaya dan lingkungan sosial mereka sebagai adaptasi terhadap lingkungan fisik dan biologisnya. Kebiasaan-kebiasaan, praktik, dan tradisi diwariskan dari generasi ke generasi. Individu-individu cenderung menerima dan percaya apa yang dikatakan budaya mereka. Manusia dipengaruhi oleh adat dan pengetahuan masyarakat di mana kita dibesarkan dan tinggal. Seseorang cenderung mengabaikan atau menolak apa yang bertentangan dengan kepercayaan-kepercayaannya. ${ }^{4}$

Oleh sebab itu, dalam konteks pendidikan pendidikan, dibutuhkan pencarian dan pengembangan kearifan-kearifan lokal (Local Wisdoms). Menggali kembali ajaran-ajaran luhur setempat guna diterapkan dalam pendidikan karakter.

Abdul Munir Mulkham, menyatakan bahwa keunikan tradisi lokal selama ini tidak ditempatkan sebagai akar kebangsaan. Kebijakan politik, termasuk

${ }^{2}$ Hamzah B. Uno, Model pembelajaran; menciptakan proses belajar mengajar yang kreatif dan efektif, (Jakarta: Bumi Aksara, 2007), h. 116

${ }^{3}$ Glynn \& Shawn. et.al. Contextual teaching and learning of science in elementary schools. Journal of Elementary Science Education.(22 September 2004)

${ }^{4}$ Philip R. Harris \& Robert T. Moran 1982, dalam intercultural communication: a reader, Al-Qalam | Volume 6 Nomor 2, 2014 
kebijakan sistem pendidikan, bersumber dari konsep monokultur. Akibatnya keunikan lokal tidak berkembang secara wajar. Karena itu kesadaran keunikan diri sebagai pengalaman otentik mesti ditempatkan sebagai akar pendidikan. ${ }^{\mathbf{5}}$

Pendidikan karakter perlu menggali dan mengembangkan kearifankearifan lokal. Penerapan kearifan-kearifan lokal (budaya sirik na pace) dalam pendidikan karakter diharapkan mampu membetuk karakter peserta didik sesuai dengan nilai-nilai yang dianut dalam daerahnya. Selain itu, mereka sadar bahwa leluhur mereka memiliki ajaran-ajaran luhur yang amat menghargai kejujuran, keadilan, dan integritas.

Berdasarkan uraian latar belakang masalah di atas, maka tulisan ini difokuskan pada konsep budaya sirik na pace dan pendidikan karakter sebagai model pembelajaran integrative. Untuk mengeksplorasi permasalahan tersebut, tulisan ini akan mengkaji konsep budaya sirik na pacce, konsep pendidikan karakter dalam proses pembelajaran, dan model pembelajaran integratif antara konsep budaya sirik na pace dan pendidikan karakter.

\section{P E M B A H A S A N}

\section{A. Konsep Budaya Sirik Na Pacce}

Dalam kehidupan orang-orang Bugis-Makassar, siri' menjadi unsur prinsipil dalam diri mereka. Siri' adalah jiwa, harga diri, dan martabat orang Bugis-Makassar. Tidak ada nilai paling berharga dan patut dipertahankan selain siri', harga diri. Dia menjadi inspirasi setiap langkah orang Bugis-Makassar. Orang Bugis-Makassar bersedia mengorbankan apapun demi tegaknya siri' dalam kehidupan mereka. Perbuatan melawan hukum merupakan perbuatan yang bertentangan dengan budaya siri'. Budaya melayani dan berbuat jujur adalah implementasi siri'. Dalam masyarakat Bugis, seseorang disebut manusia bila memiliki siri'.

Nilai budaya yang dianut adalah "PANNGADERRENG", yaitu sistem norma atau atura-aturan adat yang dianggap luhur dan keramat, terdiri dari: (1) $\boldsymbol{A D E}$ (semua usaha dalam memperistiwakan diri dalam kehidupan di semua lapangan kebudayaan), terdiri dari Ade Akkalabinengeng (hal ihwal dalam berumahtangga) dan Ade Tana (berkaitan tentang kekuasaan); (2) BICARA (semua aktivitas dan konsep-konsep yang bersangkut paut dengan peradilan (hukum acara), menentukan prosedur serta hak-hak dan kewajiban seseorang); (3) $\boldsymbol{R A P P A N G}$ (undang-undang yang berfungsi sebagai stabilitator, pembanding, dan melindungi kelompok atau perorangan); (4) WARI (melakukan klasifikasi atas segala benda, peristiwa, dan aktivitas dalam kehidupan masyarakat menurut

5 Toharudin, UUS. Kompetensi guru dalam strategi ajar. (Pikiran Rakyat. 24 Oktober 2005). 

(tata tertib garis kekeluargaan), Wari Pangoriseng (sistem hokum); (5) SARA (pranata Islam/syari'ah). ${ }^{6}$

\section{Pengertian Sirik}

Dalam pengertian harfiahnya, siri' adalah sama dengan rasa malu. Dan, kata siri' ini akan berarti harkat (value), martabat (dignity), kehormatan (honour), dan harga diri (high respect) apabila dilihat dari makna kulturalnya. ${ }^{7}$ Jadi, perlu $^{-}$ dibedakan pengertian harfiahnya dengan pengertian kulturalnya. Bagi orang Bugis-Makassar, pengertian kulturalnya itulah yang lebih menonjol dalam kehidupan sehari-hari apabila dia menyebut perkataan siri' karena siri' adalah dirinya sendiri. Siri' ialah soal malu yang erat hubungannya dengan harkat, martabat, kehormatan, dan harga diri sebagai seorang manusia. Ini mengintegrasikan semua unsur Panngaderreng yang telah disebutkan di atas, dan inilah yang paling mencerminkan nilai harga diri yang dijunjung oleh orang Bugis-Makassar. Sebagai contoh, orang Bugis-Makassar tidak akan mau pulang ke daerah asalnya apabila ia pergi merantau ke kota namun belum sukses. Ia hanya mau pulang apabila telah sukses. Contoh lain, seorang Bugis-Makassar akan berpikir panjang apabila ia ingin berhutang. Ia akan merasa sangat malu jika tidak dapat melunasi hutangnya.

Menurut orang Bugis-Makassar, orang yang tidak punya Siri' lebih baik ia mati, sehingga pelanggaran Siri' tersebut adalah pengasingan. Implikasi dari budaya Siri' ini adalah sikap kompetitif dari masyarakatnya untuk mencapai kesuksesan dan sebagai daya pendorong untuk lebih bekerja keras. Mereka akan berusaha agar tidak melanggar budaya siri' tersebut dengan tetap menjaga harga dirinya.

Siri' lebih sebagai sesuatu yang dirasakan bersama dan merupakan bentuk solidaritas. Hal ini dapat menjadi motif penggerak penting kehidupan sosial dan pendorong tercapainya suatu prestasi sosial masyarakat Bugis-Makassar. Itulah sebabnya mengapa banyak intelektual Bugis cenderung memuji siri' sebagai suatu kebajikan. Mereka hanya mencela apa yang mereka katakan sebagai bentuk penerapan siri' yang salah sasaran. Menurut mereka, siri' seharusnya - dan biasanya, memang - seiring sejalan dengan pacce'(Makassar) / pesse(Bugis).

\section{Pengertian Pacce/pesse}

Pacce/pesse dalam pengertian harfiahnya berarti " pedih ", dalam makna kulturalnya pacce berarti juga belas kasih, perikemanusiaan, rasa turut prihatin,

${ }^{6}$ A. Moein MG., Menggali Nilai-nilai Budaya Bugis-Makassar dan Sirik Na Pacce (Ujung pandang; Yayasan "Mapress", 1990), h. 116

${ }^{7}$ Pelras, Christian, Manusia bugis (terjemahan). Jakarta; Garafika Mardi Yuana, 2006), h. 251 


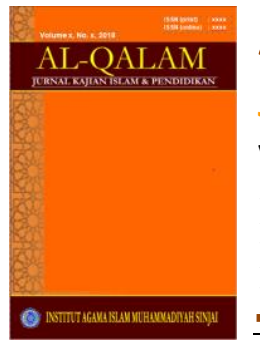

Volume 06 No 022014

ISSN (print) : : 1858-4152

ISSN (online) : -

Homepage : http://iournal.iaimsiniai.ac.id/index.php/al-qalam

berhasrat membantu, humanisme universal. ${ }^{8}$ Jadi, pacce adalah perasaan (pernyataan) solidaritas yang terbit dari dalam kalbu yang dapat merangsang kepada suatu tindakan. Ini merupakan etos (sikap hidup) orang Bugis-Makassar sebagai pernyataan moralnya. Pacce diarahkan keluar dari dirinya, sedangkan siri' diarahkan kedalam dirinya. Sirik dan pacce inilah yang mengarahkan tingkah laku masyarakatnya dalam pergaulan sehari-hari sebagai " motor " penggerak dalam memanifestasikan pola-pola kebudayaan dan sistem sosialnya.

Melalui latar belakang pokok hidup sirik na pacce inilah yang menjadi pola-pola tingkah lakunya dalam berpikir, merasa, bertindak, dan melaksanakan aktivitas dalam membangun dirinya menjadi seorang manusia. Juga dalam hubungan sesama manusia dalam masyarakat. Antara sirik dan pacce saling terjalin dalam hubungan kehidupannya, saling mengisi, dan tidak dapat dipisahkan yang satu dari lainnya.

Dengan memahami makna dari sirik dan pacce, ada hal positif yang dapat diambil sebagai konsep pembentukan hukum nasional, di mana dalam falsafah ini betapa dijunjungnya nilai-nilai kemanusiaan - berlaku adil pada diri sendiri dan terhadap sesama - bagaimana hidup dengan tetap memperhatikan kepentingan orang lain. Membandingkan konsep sirik dan pace ini dengan pandangan keadilan Plato (428-348 SM) yang mengamati bahwa justice is but the interest of the stronger (keadilan hanya merupakan kepentingan yang lebih kuat).

Masyarkat Bugis mempunyai falsafah hidup yang sangat dijunjungnya yaitu sirik na paccek. Sirik na paccek dalam masyarakat Bugis sangat dijunjung tinggi sebagai falsafah dalam segala aspek kehidupan, dan hal ini juga berlaku dalam aspek ketaatan masyakarat terhadap aturan tertentu (hukum), dengan pemahaman terhadap nilai (sirik na pacce) ini sangat mempengaruhi masyakarat dalam kehidupan hukumnya. sirik yang merupakan konsep kesadaran hukum dan falsafah masyarakat Bugis-Makassar adalah sesuatu yang dianggap sakral. Sirik na Pacce (Bahasa Makassar) atau sirik' na Pesse (Bahasa Bugis ) adalah dua kata yang tidak dapat dipisahkan dari karakter orang Bugis-Makassar dalam mengarungi kehidupan di dunia ini. Begitu sakralnya kata itu, sehingga apabila seseorang kehilangan Siri'nya atau De'ni gaga Siri'na, maka tak ada lagi artinya dia menempuh kehidupan sebagai manusia. Bahkan orang Bugis-Makassar berpendapat kalau mereka itu sirupai olo' kolo'e (seperti binatang). Petuah Bugis berkata: "Siri'mi Narituo" ( karena malu kita hidup ).

Nilai-nilai luhur siri' na pacce merupakan gambaran kecil akan nilai-nilai budaya yang berakar pada sistem, tekad, dan prinsip yang esensial. Nilai-nilai budaya siri' na pacce hakikatnya merupakan potensi dan kekayaan pola pikir yang dimiliki oleh bangsa ini dalam melahirkan sebuah kekokohan harkat dan martabat bangsa namun kini hanya tinggal sebuah cerita tanpa realita. Nilai luhur

${ }^{8}$ Ibid., h. 252

Al-Qalam | Volume 6 Nomor 2, 2014

Page 34 


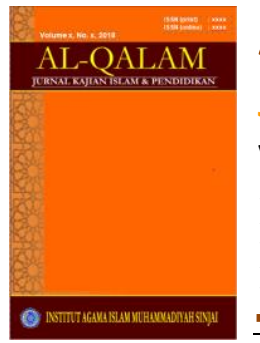

Volume 06 No 022014

ISSN (print) : 1858-4152

ISSN (online) : -

Homepage : http://iournal.iaimsiniai.ac.id/index.php/al-qalam

inilah yang seyognya menjadi landasan pacu dalam mengambil keputusan yang arif, bijaksana, dan penuh rasa tanggung jawab. Jika setiap nilai yang dipegang teguh dalam prinsip budaya siri' na pacce senantiasa di adopsi dalam pencitraan kebijakan nasional maka nilai-nilai tersebut akan menjadi pembaharu dan landasan pacu akan lahirnya sebuah stabilitas nasional karena nilai-nilai tersebut menuntut adanya sebuah kecerdasan emosional dan spiritual dalam mengontrol setiap kebijakan yang akan dilaksanakan. Ketika nilai-nilai budaya siri' na pacce telah direfleksikan dalam kurikulum pendidikan maka nilai-nilai tersebut akan mampu melahirkan sebuah sistem yang beradab karena setiap kebijakan senantiasa dilandaskan pada harga diri dan kehormatan yang menumbuhkan sebuah kesadaran untuk mengambil langkah-langkah positif demi harga diri dan kebenaran dengan mensinergikan nilai intelektual, spriritual, dan emosional.

Budaya siri' na pacce dan sejumlah budaya lainnya menyimpan sebuah kekuatan kapasitas dalam merekonstruksi sebuah tatanan pendidikan yang kian terpuruk serta membangun mentalitas dan moralitas dalam pelaksanaan system pendidikan yang jujur, adil, dan bertanggung jawab sebagai lambang kewibawaan bangsa ini sebagai instrumen control pelaksanaan roda kehidupan. Internalisasi dari nilai-nilai budaya tersebut merupakan sebuah langkah representatif dalam mengakomodasi dan mengkonsolidasi kemajemukan bangsa sebagai formulasi dalam menyusun kesamaan visi dan gerak untuk bertindak melakukan perubahan dengan penumbuhan jiwa-jiwa dan semangat berbangkit sebagai nilai prinsipil kebudayaan.

\section{B. Pendidikan Karakter}

\section{Pengertian dan Tujuan Pendidikan Karakter}

Otten, E.H. menyebutkan bahwa "Character education is an umbrella term used to describe many aspects of teaching and learning for personal development". 9 Sedangkan menurut Lickona mendefinisikan pendidikan karakter sebagai "character education is the deliberate effort to help people understand, care about, and act upon core ethical values". ${ }^{10}$ Sedangkan Santrock memberikan defenisi tentang pendidikan karakter bahwa:

Chracter education is a direct approach to moral education that involves teaching students basic moral literacy to prevent them from engaging in immoral behavior and doing harm to themselves or other. ${ }^{11}$

Awilson mendefinisikan karakter sebagai gambaran tingkah laku yang menonjolkan nilai benar-salah, baik-buruk, baik secara eksplisit maupun implisit.

${ }^{9}$ Otten, E.H.. Character education. Artikel. (September 2000).

${ }^{10}$ Elkind, D.H. \& Sweet, Freddy. How to Do Character Education. Artikel. (Sept/Okt. 2004).

11 Santrock, J.W., Educational psychology, $3^{\text {nd }}$ Editon. New York: McGrow-Hill Companies, Inc., 2008), h. 105 


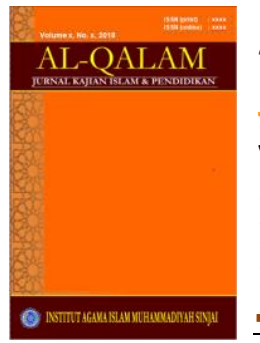

Volume 06 No 022014

ISSN (print) : 1858-4152

ISSN (online) : -

Homepage : http://iournal.iaimsinjai.ac.id/index.php/al-qalam

Pendidikan karakter merupakan gerakan nasional untuk menciptakan sekolah yang membina generasi muda yang beretika, bertanggung jawab, dan perduli melalui pemodelan dan mengajarkan karakter baik dengan penekanan pada nilai universal yang disepakati bersama. ${ }^{12}$ Ini adalah suatu usaha yang disengaja dan proaktif baik dari sekolah, daerah, dan juga negara untuk menanamkan siswanya pada nilai etika utama, seperti menghargai diri sendiri dan orang lain, bertanggung jawab, integritas, dan disiplin diri. Pendidikan karakter bukanlah suatu "perbaikan cepat" atau "obat kilat untuk semua". Dia menyediakan solusi jangka panjang pada moral, etika, dan isu akademis yang menjadi keprihatinan yang berkembang di masyarakat dan keselamatan di sekolah-sekolah. Pada kemungkinan yang terbaik, pendidikan karakter mengintegrasikan nilai positif ke setiap aspek dari hari-hari di sekolah.

Secara umum, istilah karakter sering diasosiasikan dengan apa yang disebut temperamen. Selain itu, karakter dilihat dari sudut pandang behavioral yang menekankan unsur somatopsikis yang dimiliki manusia sejak lahir. Dalam hal ini istilah karakter dianggap sama dengan kepribadian. Sedangkan kepribadian dianggap sebagai "ciri atau karakteristik atau gaya atau sifat khas dari seseorang yang bersumber dari bentukan-bentukan yang diterima dari lingkungan, misalnya keluarga pada masa kecil dan juga bawaan seseorang sejak lahir". ${ }^{13}$

Tujuan pendidikan karakter adalah mendorong lahirnya anak-anak yang baik. ${ }^{14}$ Begitu tumbuh dalam karakter yang baik, anak-anak akan tumbuh dengan kapasitas dan komitmennya untuk melakukan berbagai hal yang terbaik dan melakukan segalanya dengan benar, dan cenderung memiliki tujuan hidup. Meletakkan tujuan pendidikan karakter dalam rangka tantangan diluar kinerja pendidikan, seperti situasi kemorosotan moral dalam masyarakat yang melahirkan adanya kultur kematian sebagai penanda abad, memang bukan merupakan landasan yang kokoh bagi pendidikan karakter itu sendiri. Sebab dengan demikian, pendidikan karakter memperhambakan demi tujuan korektif, kuratif situasi masyarakat. Sekolah bukanlah lembaga demi reproduksi nilai-nilai sosial, atau demi kepentingan korektif bagi masyarakat diluar dirinya, melainkan juga mesti memiliki dasar internal yang menjadi ciri bagi lembaga pendidikan itu sendiri.

Dari uraian di atas maka dapat disimpulkan bahwa pendidikan karakter adalah sebuah proses menumbuhkan, mengembangkan dan mendewasakan kepribadian seseorang.

12 Tadkiroatun Musfiroh, Pengembangan karakter anak melalui pendidikan karakter dalam Tinjauan berbagai aspek, charcter building, (Jogyakarta: Lembaga Penelitian UNY, 2008), h.27

${ }^{13}$ Ibid.

${ }^{14}$ Ibid. 
Volume 06 No 022014

ISSN (print) : 1858-4152

ISSN (online) : -

Homepage : http://iournal.iaimsinjai.ac.id/index.php/al-qalam

\section{Nilai-nilai sebagai materi pendidikan karakter}

Hill mempunyai pendapat tentang nilai sebagai berikut:

When people speak of values they are usually referring to those beliefs held by individuals to which they attach special priority or worth, and by which they tend to order their lives. A value is, therefore, more than a belief; but it is also more than a feeling. ${ }^{15}$

Menurut Komensky ${ }^{16}$ bahwa kepada anak didik semestinya diajarkan seluruh keutamaan tanpa mengecualikannya. Ini adalah prinsip dasar pendidikan karakter, sebab sekolah merupakan sebuah lembaga yang dapat menjaga kehidupan nilai-nilai sebuah masyarakat. Untuk itu, ada beberapa kriteria nilai yang bisa menjadi bagian dalam kerangka pendidikan karakter yang dilaksanakan di sekolah. Nilai-nilai itu antara lain : nilai keutamaan, nilai keindahan, nilai patriotisme, nilai demokrasi, nilai kesatuan, nilai moral, nilai-nilai kemanusiaan, nilai keadilan dan kerjasama.

Lickona menyebutkan bahwa pendidikan karakter menekankan pentingnya tiga komponen karakter yang baik (components of good character,) yaitu sebagai berikut: bahwa moral knowing atau menyangkut pengetahuan tentang moral, moral feeling atau perasaan tentang moral dan moral action atau perbuatan bermoral. ${ }^{17}$ Hal ini diperlukan agar siswa didik mampu memahami, merasakan dan mengerjakan sekaligus nilai-nilai kebajikan. Moral Knowing, terdapat enam hal yang menjadi tujuan dari diajarkannya moral knowing yaitu: (1) moral awereness, (2) knowing moral values, (3) persperctive taking, (4) moral reasoning, (5) decision making dan (6) self-knowledge. Moral Feeling, terdapat enam hal yang merupakan aspek dari emosi yang harus mampu dirasakan oleh seseorang untuk menjadi manusia berkarakter yakni : (1) conscience, (2) selfesteem, (3) empathy, (4) loving the good, (5) self-control dan (6) humility. Moral Action, perbuatan/ tindakan moral ini merupakan hasil (outcome) dari dua komponen karakter lainnya. Untuk memahami apa yang mendorong seseorang dalam perbuatan yang baik (act morally) maka harus dilihat tiga aspek lain dari karakter yaitu: (1) kompetensi (competence), (2) keinginan (will) dan (3) kebiasaan (habit).

\section{Kurikulum dan Strategi Pendidikan Karakter}

\footnotetext{
${ }^{15}$ Stephenson, J., EvaBurman, ling, L,. et. al., Values in education, (London: Hartolis Ltd., 1998), h. 3

${ }^{16}$ Doni Koesoma, Pendidikan karakter; Strategi mendidik anak di zaman global, (Jakarta: Grasindo, 2007), h. 208

${ }^{17}$ Lickona, Thomas., Education for character, (New York: Bantam, 1999), h. 53
} 


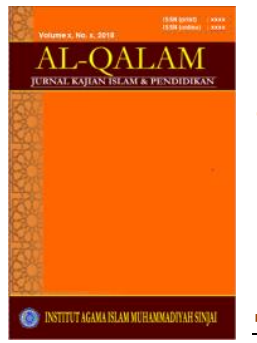

Volume 06 No 022014

ISSN (print) : 1858-4152

ISSN (online) : -

Homepage : http://iournal.iaimsinjai.ac.id/index.php/al-qalam

Kurikulum yang digunakan adalah "Kurikulum Holistik Berbasis Karakter" (Character-based Integrated Curriculum), yaitu kurikulum terpadu yang "menyentuh" semua aspek kebutuhan anak. Sebuah kurikulum yang terkait, tidak terkotak-kotak dan dapat merefleksikan dimensi, keterampilan, dengan menampilkan tema-tema yang menarik dan kontekstual. Bidang-bidang pengembangan yang ada di TK dan mata pelajaran yang ada di SD yang dikembangkan dalam konsep pendidikan kecakapan hidup yang terkait dengan pendidikan personal dan sosial, pengembangan berpikir/kognitif, pengembangan karakter dan pengembangan persepsi motorik juga dapat teranyam dengan baik apabila materi ajarnya dirancang melalui pembelajaran yang terpadu dan menyeluruh (Holistik).

Membentuk manusia secara utuh (holistik) yang berkarakter, yaitu mengembangkan aspek fisik, emosi, sosial, kreativitas, spiritual dan intelektual siswa secara optimal. Selain itu untuk membentuk manusia yang life long learners (pembelajar sejati) STRATEGI: (1) menerapkan metode belajar yang melibatkan partisipasi aktif murid, yaitu metode yang dapat meningkatkan motivasi murid karena seluruh dimensi manusia terlibat secara aktif dengan diberikan materi pelajaran yang konkrit, bermakna, serta relevan dalam konteks kehidupannya (student active learning, contextual learning, inquirybased learning, integrated learning); (2) menciptakan lingkungan belajar yang kondusif (conducive learning community ) sehingga anak dapat belajar dengan efektif di dalam suasana yang memberikan rasa aman, penghargaan, tanpa ancaman, dan memberikan semangat; (3) memberikan pendidikan karakter secara eksplisit, sistematis, dan berkesinambungan dengan melibatkan aspek knowing the good, loving the good, and acting the good; (4) metode pengajaran yang memperhatikan keunikan masing-masing anak, yaitu menerapkan kurikulum yang melibatkan juga 9 aspek kecerdasan manusia.

Menurut Elkind, D.H. \& Sweet, Freddy bahwa "Popular wisdom holds that the best way to implement character education is through a holistic approach that integrates character development into every aspect of school life". ${ }^{\mathbf{8}}$

Untuk itu, perkembangan moral anak pada usia ini sangat perlu diperhatikan oleh kedua orang tua. Menurut Santrock: "Moral development involves the development of thoughts, feelings, and behaviors regarding rules and conventions about what people should do in their interaction with other people". ${ }^{19}$ Brendt mengemukakan bahwa moral adalah prinsip atau dasar untuk menentukan

${ }^{18}$ Elkind, D.H. \& Sweet, Freddy, op.cit., h. 5

${ }^{19}$ Santrock, op.cit., h. 270 


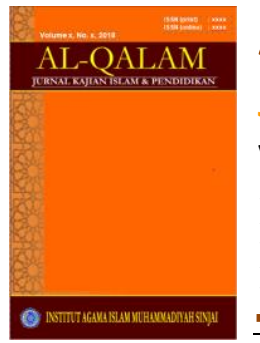

Volume 06 No 022014

ISSN (print) : 1858-4152

ISSN (online) : -

Homepage : http://iournal.iaimsiniai.ac.id/index.php/al-qalam

perilaku $^{20}$. Prinsip ini berkaitan dengan sanksi atau hukum yang diberlakukan pada setiap individu.

\section{Model Pembelajaran Integratif}

Dalam Kamus Besar Bahasa Indonesia (KBBI), integratif adalah penggabungan atau penyatuan, pembaharuan hingga menjadi kesatuan yang utuh. Menurut Suyatno, integratif berarti menyatukan beberapa ${ }^{21}$ aspek dalam satu proses. Integratif terbagi menjadi interbidang studi dan antarbidang studi. Interbidang studi artinya beberapa aspek dalam satu bidang studi kemudian diintegrasikan. Misalnya, pembelajaran berbicara diintegrasikan dengan pembelajaran menyimak dan menulis, sedangkan antarbidang studi merupakan pengintegrasian bahan dari beberapa bidang studi. Misalnya, bahasa Indonesia dengan matematika atau dengan bidang studi lainnya.

Penyampaian materi pembelajaran melalui pendekatan integratif dapat menyebabkan siswa tidak merasakan perpindahan materi, yang sebenarnya materi dalam pembelajaran itu sesungguhnya adalah tentang berbicara, tetapi diintegrasikan dengan pembelajaran menulis. Pembelajaran dengan pendekatan integratif merupakan sebuah proses pengintegrasian atau penggabungan interbidang studi.

Dalam pembelajaran, integratif interbidang studi lebih banyak digunakan saat guru menyampaikan pembelajaran berbicara yang perpindahannya diatur secara tipis. Bahkan, guru yang pandai mengintegrasikan penyampaian materi dapat menyebabkan siswa tidak merasakan perpindahan materi. Integratif sangat diharapkan dalam pembelajaran oleh kurikulum berbasis kompetensi ini. Pengintegrasiannya diaplikasikan sesuai kompetensi dasar yang perlu dimiliki siswa. Materi tidak bisa dipisah-pisahkan, materi harus dikemas secara menarik.

Oleh karena pembelajaran dilakukan dengan pendekatan integratif maka kegiatan pembelajaran dapat dilaksanakan di luar kelas, bahkan luar sekolah dengan berbagai sumber belajar. Orang tua siswa pun dapat dilibatkan dalam pembelajaran ini sedangkan guru dapat memusatkan perhatian pada pengembangan kompetensi bahasa siswa dengan menyediakan beraneka ragam kegiatan dan sumber belajar, serta guru lebih mandiri dan leluasa dalam menentukan bahan ajar sesuai dengan kondisi lingkungan sekolah dan kemampuan siswanya.

Dalam pelaksanaan kegiatan pembelajaran dengan pendekatan integratif ini kemampuan dalam aspek akan meningkat pada siswa ketika siswa melakukan

\footnotetext{
${ }^{20}$ Anita Yunus, op.cit., h. 92

${ }^{21}$ Suyatno, Teknik Pembelajaran Integratif (Surabaya; SIC, 2004), h. 26
} 


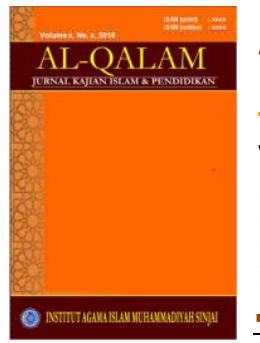

pembelajaran. Pendekatan integratif dalam peningkatan kemampuan siswa bisa dijadikan sebuah inovasi pembelajaran yang dapat meningkatkan kemampuan siswa, yakni kemampuan aktif atau produktif baik secara lisan maupun secara tertulis yang dapat dilihat pada waktu pembelajaran maupun setelah proses pembelajaran.

\section{SIMPULAN DAN REKOMENDASI}

Nilai-nilai luhur siri' na pacce merupakan gambaran kecil akan nilai-nilai budaya yang berakar pada sistem, tekad, dan prinsip yang esensial. Nilai-nilai budaya siri' na pacce hakikatnya merupakan potensi dan kekayaan pola pikir yang dimiliki oleh bangsa ini dalam melahirkan sebuah kekokohan harkat dan martabat bangsa namun kini hanya tinggal sebuah cerita tanpa realita. Nilai luhur inilah yang seyognya menjadi landasan pacu dalam mengambil keputusan yang arif, bijaksana, dan penuh rasa tanggung jawab. pendidikan karakter adalah sebuah proses menumbuhkan, mengembangkan dan mendewasakan kepribadian seseorang. Untuk itu, nilai-nilai tersebut mutlak untuk dipadukan dalam konsep pembelajran integratif dan kriteria nilai yang bisa menjadi bagian dalam kerangka pendidikan karakter yang dilaksanakan di sekolah.

\section{DAFTAR PUSTAKA}

Anita Yunus, 2008, Pengembangan karakter anak melalui pendidikan karakter dalam Tinjauan berbagai aspek, charcter building, Jogyakarta: Lembaga Penelitian UNY

A. Moein MG. 1990, Menggali Nilai-nilai Budaya Bugis-Makassar dan Sirik Na Pacce. Ujung pandang; Yayasan "Mapress".

Beni Susetyo. 2005, Politik Pendidikan Penguasa. Yogyakarta; LKiS

BSNP. 2006, Panduan umum penilaian pendidikan. Yoyakarta: Diktat

Elkind, D.H. \& Sweet, Freddy. How to Do Character Education. Artikel. (Sept/Okt. 2004).

Doni Koesoma. 2007, Pendidikan karakter; Strategi mendidik anak di zaman global. Jakarta: Grasindo

Gardner, Howard. 2003, Kecerdasan majemuk. Terjemahan Alexander Sindoro.........

Gredler, M.E. 2001, Learning and instruction theory into practice. New Jersy: Merrill Prentice Hall

Glynn \& Shawn. et.al. Contextual teaching and learning of science in elementary schools. Journal of Elementary Science Education. (22 September 2004) 


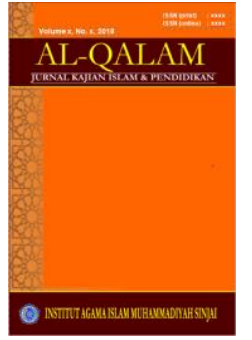

Hamzah B. Uno, 2007, Model pembelajaran; menciptakan proses belajar mengajar yang kreatif dan efektif. Jakarta: Bumi Aksara.(www.kidia.org. , diakses pada tanggal 27 Juli 2009)

Lickona, Thomas. 199, Education for character. New York: Bantam

Otten, E.H.. Character education. Artikel. (September 2000).

Philip R. Harris \& Robert T. Moran 1982, dalam intercultural communication: a reader,

Pelras, Christian, 2006, Manusia bugis (terjemahan). Jakarta; Garafika Mardi Yuana

Robert C. Bogdan dan Sari Knopp Biklen, 1998), Qualitative Research in Education: an Introduction to Theory and Methods Boston: Allyn and Bacon,

Santrock, J.W. 2008, Educational psychology, $3^{\text {nd }}$ Editon. New York: McGrowHill Companies, Inc.

Santrock, J.W. 2004, Life-Span developmenet. New York: McGrow-Hill Company, Inc.

Stephenson, J., EvaBurman, ling, L,. et. al. 1998, Values in education. London: Hartolis Ltd.

Suyatno. 2004, Teknik Pembelajaran Integratif. Surabaya : SIC

Toharudin, UUS. Kompetensi guru dalam strategi ajar. (Pikiran Rakyat. 24 Oktober 2005).

Tadkiroatun Musfiroh, 2008, Pengembangan karakter anak melalui pendidikan karakter dalam Tinjauan berbagai aspek, charcter building, Jogyakarta: Lembaga Penelitian UNY 